\title{
Relation of the hypertonic saline responsiveness of the airways to exercise induced asthma symptom severity and to histamine or methacholine reactivity
}

\author{
H K Makker, S T Holgate
}

\begin{abstract}
Background Conflicting views exist over whether responsiveness of the airways to hypertonic saline relates to nonspecific bronchial hyperresponsiveness measured by histamine or methacholine challenge. The bronchoconstrictor responses to exercise and hypertonic saline are reported to be closely related, but the relationship between the symptoms of exercise induced asthma and airway responsiveness to hypertonic saline is not known.
\end{abstract}

Methods In 29 asthmatic patients with a history of exercise induced asthma, the response to an ultrasonically nebulised hypertonic saline ( $3 \cdot 6 \%$ sodium chloride) aerosol, measured as the volume of hypertonic saline laden air required to produce a fall in forced expiratory volume in one second $\left(F_{E V}\right)$ of $\geqslant 20 \%$ $\left(\mathbf{P D}_{20}\right)$, was compared with the concentration of histamine $\left(\mathbf{P C}_{20}\right.$; group 1$)$ and methacholine $\left(\mathbf{P C}_{20}\right.$; group 2$)$ producing a $20 \%$ fall in baseline $F_{E V}$ and exercise induced asthma symptom severity score (groups 1 and 2). The hypertonic responsiveness was determined in a doseresponse manner to a maximum dose of 3101 and the exercise induced asthma symptom severity was scored on a scale of $0-5$.

Results Of the 29 patients, 23 (79\%) were responsive to the hypertonic saline, with $P_{20}$ values ranging from 9 to 3101 . A significant correlation was found between the $\mathbf{P D}_{20}$ hypertonic saline and the exercise induced asthma symptom score. There was no significant correlation between the $\mathbf{P D}_{20}$ response to hypertonic saline and the histamine $\mathbf{P C}_{20}$ or methacholine $\mathbf{P C}_{20}$. The exclusion of those subjects who failed to respond to hypertonic saline improved the relationship between hypertonic saline and methacholine $\mathbf{P C}_{20}$. No significant correlation was found between the exercise induced asthma symptom score and histamine $\mathbf{P C}_{20}$ or methacholine $\mathbf{P C}_{20}$.

Conclusion These findings suggest that hypertonic saline responsiveness bears a closer relationship to the severity of exercise induced asthma symptoms than to the non-specific bronchial hyperresponsiveness measured by histamine or methacholine reactivity.

(Thorax 1993;48:142-147)
Exercise frequently induces bronchoconstriction in asthmatic subjects. It has been suggested that exercise induced asthma results from a transient increase in the osmolarity of the airway periciliary lining fluid caused by the high rate of water loss from airways during conditioning of inspired air to body temperature and full humidity. ${ }^{1}$ A number of studies have shown that challenge of asthmatic airways with hypertonic saline aerosol produces a reduction of $20 \%$ or more in the forced expiratory volume in one second $\left(\mathrm{FEV}_{1}\right)$ in $70-100 \%$ of asthmatic subjects, confirming that hyperosmolarity is a potent stimulus for bronchoconstriction. ${ }^{2-6}$ The bronchoconstrictor response to exercise and hypertonic aerosol are reported to be closely related. ${ }^{6}$ At least one component thought to contribute to the magnitude of the exercise response in asthma is the underlying level of non-specific bronchial hyperresponsiveness. While some studies have shown a correlation between the two responses, ${ }^{78}$ others have not. ${ }^{69}$ Conflicting views also exist over whether responsiveness of the airways to hypertonic saline relates to bronchial hyperresponsiveness measured by histamine or methacholine challenge. Smith et al ${ }^{5}$ showed a significant correlation between the methacholine reactivity and the hypertonic response in a group of asthmatic subjects with moderate to severe bronchial hyperresponsiveness (mean $\mathrm{PD}_{20}$ methacholine, $0.68 \mu \mathrm{mol}$ ). Belcher $e t a l^{6}$ have reported similar results for histamine. Using a quantitative method to determine the hypertonic saline response in asthmatic subjects and a wider range of methacholine reactivity, Boulet et al, however, could not establish any correlation between the hypertonic saline response and methacholine reactivity. ${ }^{4}$

In this study we have assessed the contribution of non-specific bronchial hyperresponsiveness to the hypertonic saline response in asthmatics by re-examining the relationship between the hypertonic saline response and histamine and methacholine reactivity. We have also studied the relationship between the perceived severity of symptoms of exercise induced asthma and airway responsiveness to hypertonic saline, histamine, and methacholine.

Methods

PATIENTS

Twenty nine asthmatic patients (17 male, 12 female) of mean (SE) age $29 \cdot 6(1 \cdot 7)$ years, 
with a clear history of exercise induced asthma, participated in the study. All were asked to score the severity of their symptoms of exercise induced asthma over the previous three months on a scale of $0-5$ based on asthma severity scores used in previous studies ${ }^{10-12}$ ( $0=$ no symptoms, $1=$ mild, $2=$ mild to moderate, 3 =moderate, $4=$ moderate to severe, $5=$ severe). They were all non-smokers and 28 were atopic on skin prick testing as judged by $>3 \mathrm{~mm}$ weals in response to at least one of five common allergens (mixed grass pollen; Dermatophagoides pteronyssinus; dog, feather, and cat extracts: Bencard, Brentford, Middlesex, UK). Fifteen patients were taking inhaled $\beta_{2}$ agonists alone as required, while 14 also used regular inhaled corticosteroid (beclomethasone dipropionate). Their mean (SE) percentage predicted $\mathrm{FEV}_{1}$ was $92 \cdot 9(2 \cdot 4)$. They were randomly allocated to one of two groups to be challenged with either histamine (group 1) or methacholine (group 2).

Group 1 consisted of 15 patients, 11 male and four female, of mean (SE) age 29.7 (3.9) years with a mean (SE) percentage predicted $\mathrm{FEV}_{1}$ of $92 \cdot 3$ (3.1) (table 1).

Group 2 consisted of 14 patients, six male and eight female, of mean (SE) age 29.6 (2.6) years with a mean (SE) percentage predicted $\mathrm{FEV}_{1}$ of 93.6 (3.9) (table 2).

All the subjects gave written informed consent and the study was approved by Southampton University and Hospitals Joint Ethical Subcommittee.

\section{STUDY DESIGN}

On the first visit the patients in group 1 received a histamine challenge while those in group 2 received a methacholine challenge. Within one week of their first visit, all returned to the laboratory at the same time of day as on their first visit and received a hypertonic saline challenge. Inhaled $\beta_{2}$ agonists were withheld for eight hours before each visit to the laboratory; topical corticosteroids were continued as usual.

\section{Bronchial provocation}

Histamine/methacholine challenge This was performed with the five breath technique modified from that of Chai and colleagues. ${ }^{13}$ The lowest concentration of histamine monophosphate or methacholine used was $0.03 \mathrm{mg} / \mathrm{ml}$, and doubling concentrations were administered to a maximum of 16 $\mathrm{mg} / \mathrm{ml}$. Before the challenge a baseline $\mathrm{FEV}_{1}$ was obtained, which was the highest of three technically satisfactory recordings obtained with a dry wedge spirometer (Vitalograph, Buckingham, UK). The patients were then instructed to take five deep breaths of aerosol from functional residual volume to total lung capacity from an Inspiron nebuliser, from which normal saline was nebulised with compressed air at a flow rate of $81 / \mathrm{min}$. Two measurements of $\mathrm{FEV}_{1}$ were performed at three minutes, with the higher value being accepted. If the $\mathrm{FEV}_{1}$ obtained after saline administration was within $10 \%$ of baseline $\mathrm{FEV}_{1}$, the histamine or methacholine challenge was undertaken. Increasing doubling concentrations of agonist were administered at three minute intervals until a $20 \%$ fall in $\mathrm{FEV}_{1}$ from the value obtained after saline administration was recorded. From a plot of the percentage fall in $\mathrm{FEV}_{1}$ against the natural logarithm of the cumulative agonist concentration, the provocation concentration of histamine or methacholine giving a $20 \%$ fall in $\mathrm{FEV}_{1}\left(\mathrm{PC}_{20}\right)$ was derived by linear interpolation.

Hypertonic saline challenge The nebuliser used to deliver hypertonic saline was a DeVilbiss model 65 ultrasonic nebuliser (DeVilbiss, Feltham, Middlesex, UK). We have previously shown that the output of hypertonic saline to the mouthpiece is linearly related to the volume of air drawn through the nebuliser, with an output of $10.8 \mathrm{ml} / 100 \mathrm{l}$ of air at the chosen nebuliser setting. ${ }^{14}$

The hypertonic saline $(3.6 \% \mathrm{NaCl})$ challenge was given in a dose-response manner. Two measurements of $\mathrm{FEV}_{1}$ were made for each patient, and the higher reading was used

Table 1 Baseline percentage of predicted $F E V_{1}$, exercise induced asthma (ELA) symptom score and airway response to histamine and hypertonic challenge (group 1)

\begin{tabular}{|c|c|c|c|c|c|c|}
\hline $\begin{array}{l}\text { Patients } \\
\text { No. }\end{array}$ & $\begin{array}{l}\text { Age } \\
\text { (years) }\end{array}$ & Sex & $\begin{array}{l}F E V_{1}(\% \\
\text { predicted) }\end{array}$ & $\begin{array}{l}\text { EIA symptom } \\
\text { score }(0-5)\end{array}$ & $\begin{array}{l}P C_{20}(H) \\
(m g / m l)\end{array}$ & $\begin{array}{l}P D_{20}(3 \cdot 6 \% \mathrm{NaCl}) \\
\text { (itres) }\end{array}$ \\
\hline $\begin{array}{l}1 \\
2 \\
3 \\
4 \\
5 \\
6 \\
7 \\
8 \\
9 \\
10 \\
11 \\
12 \\
13 \\
14 \\
15 \\
\text { Mean } \\
\text { SEM }\end{array}$ & $\begin{array}{l}24 \\
34 \\
30 \\
18 \\
36 \\
43 \\
23 \\
36 \\
23 \\
33 \\
22 \\
25 \\
54 \\
33 \\
21 \\
29 \cdot 66 \\
3 \cdot 87\end{array}$ & $\begin{array}{l}\mathbf{M} \\
\mathbf{F} \\
\mathbf{M} \\
\mathbf{M} \\
\mathbf{M} \\
\mathbf{M} \\
\mathbf{F} \\
\mathbf{M} \\
\mathbf{M} \\
\mathbf{M} \\
\mathbf{F} \\
\mathbf{F} \\
\mathbf{M} \\
\mathbf{M} \\
\mathbf{M}\end{array}$ & $\begin{array}{l}77 \\
108 \\
100 \\
77 \\
99 \\
92 \\
105 \\
85 \\
73 \\
78 \\
109 \\
101 \\
97 \\
98 \\
85 \\
92 \cdot 27 \\
3 \cdot 14\end{array}$ & $\begin{array}{l}3 \\
3 \\
4 \\
4 \\
2 \\
4 \\
5 \\
4 \\
3 \\
5 \\
4 \\
4 \\
3 \\
2 \\
3\end{array}$ & $\begin{array}{l}2 \cdot 80 \\
3.40 \\
0 \cdot 22 \\
0 \cdot 68 \\
2.41 \\
0 \cdot 89 \\
13 \cdot 7 \\
1 \cdot 99 \\
0 \cdot 19 \\
0 \cdot 25 \\
2 \cdot 70 \\
2 \cdot 60 \\
1.28 \\
1.70 \\
0.41 \\
\star 1.16\end{array}$ & $\begin{array}{l}155 \\
36 \\
9 \\
101 \\
231 \\
9 \\
139 \\
26 \\
124 \\
157 \\
10 \\
59 \\
295 \\
\text { NR } \\
\text { NR }\end{array}$ \\
\hline
\end{tabular}

^Geometric mean.

$\mathrm{PC}_{20} \mathrm{H}$-concentration of histamine producing a $20 \%$ fall in the baseline $\mathrm{FEV}_{1} ; \mathrm{PD}_{20}(3.6 \% \mathrm{NaCl})$-volume of hypertonic saline ond; EIA - exercise induced asthma. 
Table 2 Baseline percentage of predicted $F E V_{1}$, exercise induced asthma (ELA) symptom score and airway response to methacholine and hypertonic challenge (group 2)

\begin{tabular}{|c|c|c|c|c|c|c|}
\hline $\begin{array}{l}\text { Patient } \\
\text { No }\end{array}$ & $\begin{array}{l}\text { Age } \\
\text { (years) }\end{array}$ & Sex & $\begin{array}{l}F E V_{1} \\
\text { (\% predicted) }\end{array}$ & $\begin{array}{l}\text { ELA symptom } \\
\text { score }(0-5)\end{array}$ & $\begin{array}{l}P C_{20}(M) \\
(m g / m l)\end{array}$ & $\begin{array}{l}P D_{20}(3 \cdot 6 \% \mathrm{NaCl}) \\
\text { (itres) }\end{array}$ \\
\hline $\begin{array}{l}16 \\
17 \\
18 \\
19 \\
20 \\
21 \\
22 \\
23 \\
24 \\
25 \\
26 \\
27 \\
28 \\
29 \\
\text { Mean } \\
\text { SEM }\end{array}$ & $\begin{array}{l}31 \\
25 \\
24 \\
18 \\
25 \\
23 \\
24 \\
39 \\
30 \\
28 \\
27 \\
30 \\
54 \\
26 \\
29 \cdot 62 \\
2.58\end{array}$ & $\begin{array}{l}F \\
F \\
F \\
M \\
M \\
F \\
F \\
M \\
F \\
F \\
F \\
M \\
M \\
M\end{array}$ & $\begin{array}{l}77 \\
97 \\
84 \\
95 \\
125 \\
89 \\
76 \\
106 \\
101 \\
96 \\
96 \\
91 \\
69 \\
109 \\
93.64 \\
3.90\end{array}$ & $\begin{array}{l}4 \\
5 \\
5 \\
5 \\
4 \\
4 \\
3 \\
4 \\
2 \\
1 \\
2 \\
2 \\
2 \\
1\end{array}$ & $\begin{array}{l}0.06 \\
0.17 \\
5.78 \\
0.25 \\
0.92 \\
0.34 \\
0.04 \\
1.43 \\
4.00 \\
0.89 \\
0.50 \\
0.13 \\
0.12 \\
14.5 \\
\star 0.77\end{array}$ & $\begin{array}{l}25 \\
88 \\
102 \\
72 \\
310 \\
83 \\
60 \\
33 \\
293 \\
304 \\
\text { NR } \\
\text { NR } \\
\text { NR } \\
\text { NR }\end{array}$ \\
\hline
\end{tabular}

*Geometric mean

$\mathrm{PC}_{20}(\mathrm{M})$ - concentration of methacholine producing a $20 \%$ fall in the baseline $\mathrm{FEV}_{1} ; \mathrm{PD}_{20}(3 \cdot 6 \% \mathrm{NaCl})$-volume of hypertonic

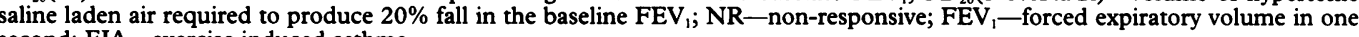
second; EIA - exercise induced asthma.

as the first baseline. They were then asked to breathe at tidal volume through the mouthpiece, with the nebuliser switched off, until 251 of air had been respired. Two further estimations of $\mathrm{FEV}_{1}$ were made, and the higher reading was taken as the new baseline. If the new baseline differed from the first by more than $10 \%$, the procedure was discontinued, although this was not necessary for any of the patients during the study. The nebuliser was then switched on and, wearing a nose clip, the patient was instructed to breathe quietly through the mouthpiece. After he or she had breathed 51 of hypertonic saline laden air, single recordings of $\mathrm{FEV}_{1}$ were made at 30,90 , and 180 seconds. If any $\mathrm{FEV}_{1}$ estimation was technically poor because of coughing, it was repeated after 30 seconds. If the $\mathrm{FEV}_{1}$ had fallen by over $20 \%$ from the new baseline $F E V_{1}$ value, the test end point had been reached. If not, a further volume of air was respired and the same procedure repeated. The volumes used were: $5,10,15$, 20, 20, 25, 35, 40, 40, 50, and 501 (BTPS), administered in this sequence until a greater than $20 \%$ fall in $\mathrm{FEV}_{1}$ had occurred, or a total volume of $310 \mathrm{l}$ of hypertonic saline laden air had been respired.

The dose of hypertonic saline administered was expressed as the volume of air drawn from the nebuliser and plotted on a linear scale against the percentage fall in $\mathrm{FEV}_{1}$. The provocative volume of hypertonic saline laden air required to induce a $20 \%$ fall in $\mathrm{FEV}_{1}\left(\mathrm{PD}_{20}\right)$ was calculated by linear interpolation.

\section{DATA ANALYSIS}

The patients were randomised according to random number allocation. They were ranked according to their response to the hypertonic saline, histamine and methacholine challenge, and the exercise induced asthma symptom severity score. The degrees of correlation between the $\mathrm{PD}_{20}$ hypertonic saline, the $\mathrm{PC}_{20}$ histamine and methacholine, and the exercise induced asthma symptom score were examined by Spearman's rank correlation. The correlations were made with the Spearman's correlation coefficient because we were able to include all patients in the analysis by ranking those who did not respond to hypertonic saline (Nos 14, 15, 27, 28, and 29) equal last. A level of $p<0.05$ was taken as significant.

\section{Results}

Hypertonic saline produced bronchoconstriction amounting to a reduction of at least $20 \%$ of the baseline $\mathrm{FEV}_{1}$ in $23(79 \%)$ of the 29 patients; $\mathrm{PD}_{20}$ values varied from 91 to 3101 (figure). A highly significant correlation was found between the response to hypertonic saline measured as the $\mathrm{PD}_{20}$ and the exercise induced asthma symptom score $\left(r_{s}=0.5\right.$; $\mathrm{p}=0 \cdot 002$ ).

GROUP 1

The histamine $\mathrm{PC}_{20}$ values ranged from $0 \cdot 19$ to $13.7 \mathrm{mg} / \mathrm{ml}$ (geometric mean $1.16 \mathrm{mg} / \mathrm{ml}$ ). Thirteen of the 15 subjects $(87 \%)$ responded with a fall in $\mathrm{FEV}_{1}$ of $20 \%$ or more with hypertonic saline challenge $\left(\mathrm{PD}_{20}\right.$ range 9-295 1). The correlation between $\mathrm{PD}_{20}$ hypertonic saline and exercise induced asthma symptom score $\left(\mathrm{r}_{\mathrm{s}}=0 \cdot 27, \mathrm{p}=0 \cdot 15\right)$ did not reach significance. The correlation between $\mathrm{PD}_{20}$ hypertonic saline and $\mathrm{PC}_{20}$ histamine was not significant $\left(r_{s}=0.05, p=0.43\right)$. No correlation could be found between the exercise induced asthma symptom score and $\mathrm{PC}_{20}$ histamine reactivity $(r=0 \cdot 17, p=0 \cdot 26)$.

\section{GROUP 2}

The methacholine $\mathrm{PC}_{20}$ ranged from 0.04 to $14.5 \mathrm{mg} / \mathrm{ml}$ (geometric mean $0.77 \mathrm{mg} / \mathrm{ml}$ ). Ten of the 14 subjects $(71 \%)$ responded to the hypertonic saline $\left(\mathrm{PD}_{20}\right.$ range 25-310 1). There was a significant correlation between hypertonic saline $\mathbf{P D}_{20}$ and exercise induced asthma symptom score $\left(r_{s}=0.62, p=0.008\right)$ in this group. No correlation could be established between $\mathrm{PD}_{20}$ hypertonic saline response and $\mathrm{PC}_{20}$ methacholine $\left(r_{s} \quad 0.26\right.$, $\mathrm{p}=0 \cdot 18$ ). On removal of the subjects who did not respond to hypertonic saline, however, there was a trend towards a significant relationship between hypertonic saline and methacholine responsiveness $\quad\left(r_{s}=0.52\right.$, 
The Spearman's ranked correlation $\left(r_{S}\right)$ between the response to hypertonic saline and exercise induced asthma (ELA) symptom score (top, groups 1 and 2), methacholine reactivity (middle, group 2), and histamine reactivity

(bottom, group 1). The hypertonic saline response was ranked from most responsive (lowest $P D_{20}$ ) to non-responsive $\left(P D_{20}>310 l\right)$, histaminel methacholine from lowest $P C_{20}$ to highest $P C_{20}$, and ELA symptom score from no symptoms (lowest score) to severe symptoms (highest score).
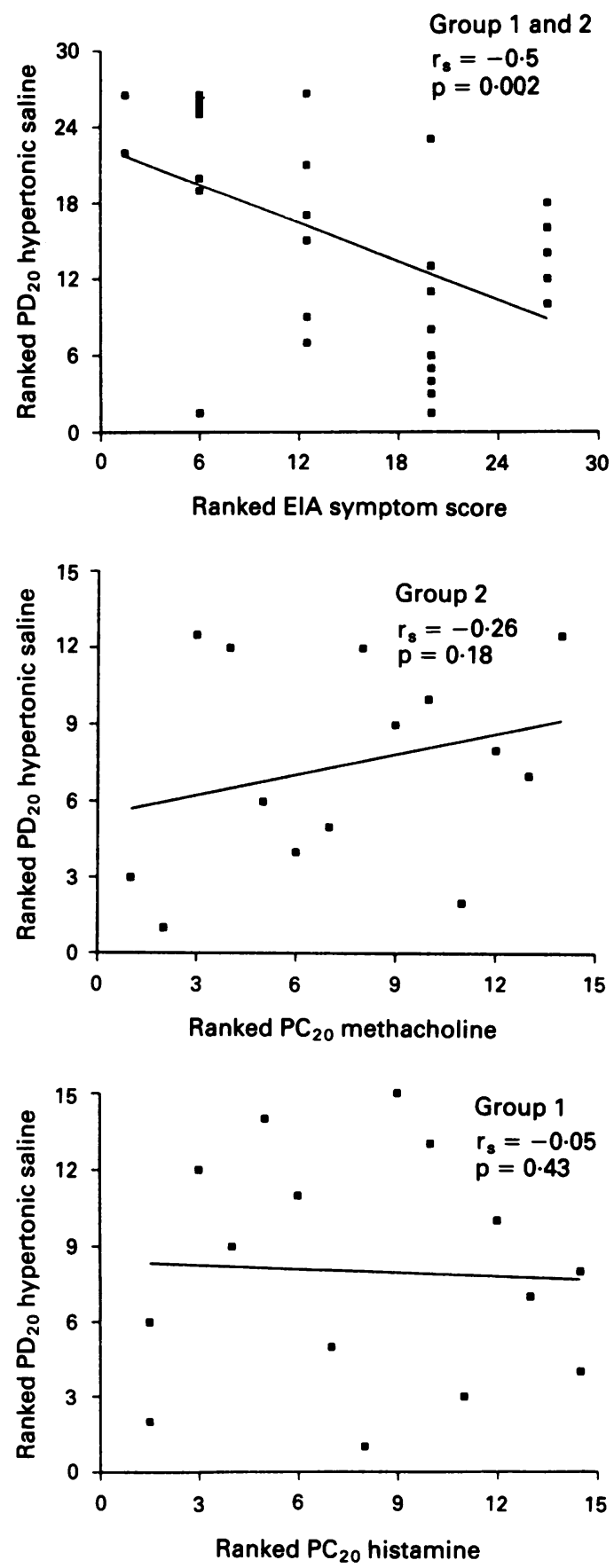

$p=0 \cdot 05)$. No significant relation could be found between the exercise induced asthma symptom score and the methacholine reactivity $\left(r_{s}=0 \cdot 12, p=0 \cdot 33\right)$.

\section{Discussion}

In this study we failed to find any significant relationship between the level of airway responsiveness to hypertonic saline and nonspecific bronchial hyperresponsiveness measured with histamine or methacholine. A similar result has also been shown by Boulet et $a l,{ }^{4}$ who used a quantitative method to measure the hypertonic saline response with doubling concentrations of saline from $0.9 \%$ to $14.4 \%$ to obtain a dose-response curve, and expressed the level of hypertonic responsiveness as the osmolarity causing a $20 \%$ fall in $F_{E V}\left(P_{20}\right)$ in asthmatic subjects with methacholine $\mathrm{PC}_{20}$ values of $0 \cdot 19-5 \cdot 54$ $\mathrm{mg} / \mathrm{ml}$. Belcher et $a l^{6}$ reported a significant correlation between the hypertonic saline and the histamine reactivity in asthmatic subjects responsive to hypertonic saline who had moderate histamine reactivity (geometric mean $\mathrm{PC}_{20}$ histamine, $1.08 \mathrm{mg} / \mathrm{ml}$ ). Smith et al have also reported a significant correlation between the hypertonic response and the methacholine reactivity; in this study, however, the subjects had moderate to severe methacholine responsiveness (geometric mean $\mathrm{PC}_{20}$ methacholine, $\left.0.68 \mu \mathrm{mol}\right)$. In the present study, exclusion of those subjects whose airways failed to respond to hypertonic saline improved the correlation with methacholine $\mathrm{PC}_{20}$, which suggests that in this subgroup the severity of underlying "nonspecific" hyperresponsiveness may bear some relation to the degree of hypertonic response. The failure of this study to detect a relationship between bronchial hyperresponsiveness and hypertonic saline response may be due to the relatively small number of subjects used in each part of the study. Such a study would therefore only be likely to detect a strong relationship and the possibility that a weaker relationship does exist has not been excluded, nor has a relationship applying only to a subgroup of subjects such as those with severe bronchial hyperresponsiveness.

The exact mechanisms of hypertonic saline induced bronchoconstriction are not known. In the knowledge that selective $\mathrm{H}_{1}$ receptor antagonism removes the majority of the response, ${ }^{14}$ one suggested mechanism might involve the release of mediators from mucosal mast cells. ${ }^{15}$ Anticholinergic drugs also offer some variable degrees of protection, possibly implicating a neuronal reflex mechanism as a result of the loss of epithelial integrity. ${ }^{15}$ How much these mechanisms contribute to the overall bronchoconstrictor response is not known, but contributions are likely to vary from subject to subject as with exercise induced asthma. Bronchoconstriction provoked by the cholinergic agonist methacholine occurs by direct interaction with the muscarinic $\mathrm{M}_{3}$ receptors linked to excitationcontraction coupling of airway smooth muscle. ${ }^{16}$ In the case of histamine, the constrictor response is due to a combination of smooth muscle contraction both directly and indirectly through neural reflexes and microvascular leakage, all involving $\mathrm{H}_{1}$ receptors. ${ }^{16}$ In view of the different mechanisms of action of hypertonic saline, histamine, and methacholine in evoking bronchoconstriction, it is not surprising that a relationship between the former probably indirect and the latter more direct stimuli could not be found.

In previous studies severity of asthma has been assessed in terms of symptoms and other features of the history, degree of airflow obstruction, and level of treatment needed to control symptoms. Each of these has its imitations. ${ }^{17}$ While measurements of $\mathrm{FEV}_{1}$ and peak expiratory flow rate (PEF) are both invaluable in assessing the degree and variability of obstruction of airflow, reduction 
in airway calibre may occur over short periods of time and is not revealed by intermittent measurements. Bronchial hyperresponsiveness is a functional abnormality and might reflect underlying pathological processes in the airway rather than a relationship with the current degree of bronchoconstriction measured at any one time. Makino ${ }^{10}$ and Murray et al ${ }^{11}$ have reported a stronger correlation between the asthma history score and $\mathrm{PC}_{20}$ histamine than between asthma score and any spirometric test in asthmatic subjects who were apparently free of airway obstruction at the time of testing. Similarly, exercise induced bronchoconstriction has been shown to correlate with wheezing score, but not with pre-exercise PEF. ${ }^{12}$

In the present study we have shown a relationship between the exercise induced asthma symptom score and bronchial responsiveness to hypertonic saline, histamine, and methacholine. The close relationship observed between the exercise induced asthma symptom score and the hypertonic saline response confirms the findings of Belcher et al, ${ }^{6}$ who showed a significant correlation between the level of hypertonic responsiveness and exercise induced bronchoconstriction. The failure of our study to show an association between a symptom score for exercise induced asthma and both histamine and methacholine responses adds to the view that exercise induced asthma is a more complex expression of airway hyperresponsiveness than the simple measurement of histamine or methacholine $\mathrm{PC}_{20}$. While there are studies showing a correlation between exercise induced asthma and histamine and methacholine reactivity, these have always been conducted on selected patient populations. ${ }^{78}$ When subjects were selected from the community on the basis of respiratory symptoms alone, the degree of bronchoconstriction provoked by exercise failed to relate to methacholine responsiveness. ${ }^{9}$

The significant correlation observed between the exercise induced asthma symptom score and hypertonic saline response, compared with the lack of association between the symptom score for exercise induced asthma and both histamine and methacholine response, is probably partly due to the larger number of subjects in the hypertonic saline group. We therefore examined the correlation between exercise induced asthma and hypertonic response in the two subgroups; no significant correlation was found in the histamine subgroup (group 1), but in the methacholine subgroup the correlation was still significant (group 2). However, in both subgroups the relationship between exercise induced asthma symptom score and hypertonic saline was closer than the relationship between exercise induced asthma symptom score and both histamine and methacholine response. Further studies with larger numbers of patients are needed to confirm these findings.

The response rate of $79 \%$ to hypertonic saline challenge in subjects with a history of exercise induced asthma is similar to that reported in other studies. ${ }^{2-5}$ Two possible mechanisms have been advanced for the pathogenesis of exercise induced asthma. Smith and Anderson have presented a strong argument that the hypertonicity of the airway lining fluid resulting from conditioning of inspired air to body temperature and humidity is a sufficient stimulus to account for the release of mediator from mucosal mast cells and bronchoconstrictor response to exercise. ${ }^{15}$ This argument is supported by the facts that $\mathrm{H}_{1}$ histamine antagonists are highly effective in inhibiting the airways response to exercise $^{18}$ and that a leukotriene receptor antagonist markedly attenuates exercise induced bronchoconstriction. ${ }^{19} \mathrm{McF}$ adden et al have suggested an alternative mechanism from detailed studies of temperature gradients down the airway during exercise induced asthma, and hypothesised that airway cooling followed by rebound hyperaemia might be responsible for the reduction in airway calibre. ${ }^{20}$ Our finding that the perception of severity of exercise induced asthma by patients relates closely to the level of airway responsiveness to hypertonic aerosol challenge supports a link between hypertonicity and the mechanisms of exercise induced asthma. That the two types of challenge share a common pathway is further supported by cross refractoriness between the two stimuli. ${ }^{21}$

We therefore conclude that airway responsiveness to hypertonic saline relates more closely to the symptom severity of exercise induced asthma than to histamine or methacholine reactivity. These findings reinforce the view that hypertonic saline induced bronchoconstriction is a challenge model that closely reflects the mechanisms of exercise induced asthma.

1 Anderson SD: Is there unifying hypothesis for exerciseinduced asthma? ₹ Allergy Clin Immunol 1984;73:660-5. Anderson SD, Schoeffel RE, Finney M. Evaluation of ultrasonically nebulised solutions for provocation testing in patients with asthma. Thorax 1983;38:284-91.

3 Smith CM, Anderson SD. Hyperosmolarity as the stimulus to asthma induced by hyperventilation? $\mathcal{f}$ Allergy Clin Immunol 1986;77:729-36.

4 Boulet LP, Legirs C, Thibault L, Turcotte H Comparative bronchial responses to hyperosmolar salin and methacholine in asthma. Thorax 1987;42:953-8.

5 Smith CM, Anderson SD, Black JL. Methacholine responsiveness increases after ultrasonically nebulised water but not after ultrasonically nebulised saline in patients with asthma. $\mathcal{F}$ Allergy Clin Immunol 1987;79: 85-92.

6 Belcher NG, Lee TH, Rees PJ. Airway response to hypertonic saline, exercise and histamine challenges in tonic saline, exercise and histamine chall

7 Bleecker ER, Chatham M, Smith PL, Mason PI Norman PS. Airway responses to conditioned air methacholine, histamine, and exercise in asthmatics and methacholine, histamine, and exercise in

8 Deal EC, McFadden ER, Ingram RH, et al. Hyperpnoea and heat flux: initial reaction sequence in exerciseinduced asthma. F Appl Physiol 1979;46:476-83.

9 Clough JB, Hutchinson SA, Williams JD, Holgate ST Airway response to exercise and methacholine in children with respiratory symptoms. Arch Dis Child 1991; 66:579-83

10 Makino S. Clinical significance of bronchial sensitivity to acetylcholine and histamine in bronchial asthma. Allergy 1966;38:127-42.

11 Murray AB, Latimer KM, Ferguson AC, Morrison B. Airway responsiveness to histamine as a test for overall severity of asthma in children. $\mathcal{F}$ Allergy Clin 1981;68:119-24. 
12 Sly RM. Exercise-related changed in airway obstruction: frequency and clinical correlates in asthmatic children. Ann Allergy 1970;28:1-16.

13 Chai H, Farr RS, Froehlich LA, et al. Standardisation of bronchial inhalation challenge procedures. $\mathcal{f}$ Allergy Clin Immunol 1975;56:323-7.

14 Finnerty JP, Wilmot C, Holgate ST. Inhibition of hypertonic saline-induced bronchoconstriction by terfenadin and flurbiprofen. Am Rev Respir Dis 1989;140:593-7.

15 Smith CM, Anderson SD. Inhalation provocation tests using non-isotonic aerosols. $\mathcal{F}$ Allergy Clin Immuno $1989 ; 84: 781-90$

16 Sterk PJ, Bel EH. Fundamental aspects of airway hyperresponsiveness. In: Kerrebijin KF, Sluter HJ, eds. Nocturnal dyspnea, inflammation and reactivity. Rijswijk, The Netherlands: Astra, 1986: 73-91.

17 Josephs LK, Gregg I, Holgate ST. Does non-specific bronchial responsiveness indicate the severity of asthma?
Eur Respir 7 1990;3:220-7.

18 Finnerty JP, Holgate ST. Evidence for the role of histamine and prostaglandins as mediators in exercisemine and prostaglandins as mediators in exerciseflurbiprofen alone and in combination. Eur Respir $\mathcal{f}$ 1990;3:540-7.

19 Manning PJ, Watson RM, Margolskee DJ, Williams VC, Schwartz JI, O'Byrne PM. Inhibition of exerciseinduced bronchoconstriction by MK-571, a potent leukotriene $\mathrm{D}_{4}$-receptor antagonist. $N$ Engl f $\mathrm{Med} 1990$; 323:1736-9.

20 McFadden ER Jr, Lenner KA, Strohl KP. Post-exertional airway rewarming and thermally induced asthma. $f$ Clin Invest 1986;78:18-25.

21 Belcher NG, Rees JR, Clark JH, Lee TH. A comparison of the refractory periods induced by hypertonic airway challenge and exercise in bronchial asthma. Am Rev Respir Dis 1987;135:822-5. 